ACTA AGROBOTANICA

Vol. 58, z. $2-2005$

s. $329-334$

\title{
Characteristics of wheat leaf diseases development in Latvia
}

\author{
BIRUTA BANKINA ${ }^{1}$, ILZE PRIEKULE ${ }^{2}$ \\ ${ }^{1}$ Department of Plant Biology and Protection, Latvia University of Agriculture \\ ${ }^{2}$ Latvian Plant Protection Research Centre, Jelegava
}

(Received: 18.04.2005)

Summary

The field observations were carried out in 1999-2004 on 29 fields in Latvia. Incidence and severities of wheat leaf diseases were determined. Tan pot caused by Drechslera tritici-repentis and Septoria leaf blotch, induced by Septoria tritici were the most harmful diseases at the time of research (incidence $10-100 \%$ and $1-100 \%$, respectively). Also the incidence of powdery mildew, caused by Blomeria graminis was high (4-100\%), while that of rusts (Puccinia tritici and P. striiformis) was very low. Changes in disease epidemics were determined and showed the differences between the analyzed diseases.

Key words: wheat, tan spot, Septoria leaf spot, powdery mildew, disease progress

\section{INTRODUCTION}

Winter wheat is one of the most important cereal crops in Latvia. Diseases, especially leaf diseases, of wheat are causing important losses of the yield. Since the 1990 wheat has been grown under increasingly intensive management regimes in part of the farms. These changes in the cropping system have increased incidence and severity of the wheat diseases (B a n k in a, 2002). Assessment of incidence and severity of each disease and epidemics analysis are the main tasks for the present.

Changes in the epidemics of disease are reflected by alterations in the disease progress curve. The most important parameters are rate of infection, shape of the curve and area under the disease progress curve (C a m p b e 11 and M a d d e n, 1990). 
The primary infections of winter wheat crops by leaf spot diseases - tan spot, caused by Drechslera tritici-repentis (teleomorph Pyrenophora tritici-repentis) and Septoria leaf blotch, brought about by Septoria tritici (teleomorph Mycosphaerella graminicola) are initiated in autumn by air-borne ascospores of the teleomorph stage, which originate from sources outside the crop.The subsequent disease development was commonly ascribed to the anamorph stage, which develops to give rise to splashborne conidia. (F r a n c 1, 1998; H u n t e r et al., 1999).

Powdery mildew, caused by Blumeria graminis was observed every year, but it is harmful only in some cases under the conditions of Latvia. Development of powdery mildew depends mainly on wheat density, level of nitrogen and variety. Leaf spot diseases were recorded to a rather high level in the research period, especially $\tan$ spot.

The detailed studies of the life cycle, distribution and dynamics of development of wheat leaf diseases help to understand better the development and propagation of diseases what may improve control strategy.

\section{MATERIAL AND METHODS}

The field observations were carried out in different localities during 1999-2004. Development of diseases was investigated in areas without fungicide application. Different wheat varieties were included into the research program, total number of observation areas -29 .

All agronomic requirements were noticed in the observation areas. Seed dressing, herbicides and high doses of nitrogen were applied in all the cases.

Assessments of diseases were made on the upper three leaves every week from the start of stem elongation (GS 31) to dough stage (GS 85). Incidence and severity of diseases were determined (expressed in \%).

Causal agents of diseases were determined in a laboratory by investigation of pycnidias and morphology of conidiophores and conidia. Moist chambers were used for development of conidia.

Average severity and incidence were calculated for analyzing the economic importance of diseases.

The meteorological conditions were rather different during the experimental period. The season was extremely dry in 1999 restricting the development of diseases. A similar situation was observed in 2002. Vegetation seasons of 2000, 2003 and particularly of 2001 and 2004 were favorable for the diseases development, with the wet and rainy summer stimulating the occurrence of leaf spot diseases. 


\section{RESULTS}

Leaf blotch diseases - tan spot, caused by Drechslera tritici-repentis (teleomorph Pyrenophora tritici-repentis) and Septoria leaf blotch, induced by Septoria tritici (teleomorf Mycosphaerella graminicola) were the most harmful diseases during the experimental period in Latvia. The occurrence of mildew, caused by Blumeria graminis was also rather high $-83 \%$. Brown rust (Puccinia tritici) and yellow rust (P. striiformis) was reported rather seldom and only after flowering, severity of diseases did not exceed some percent.

Occurrence does not give an idea of harmfulness of a disease. Incidence and especially severity are substantial indicators of the economic importance of a disease.

Incidence of mildew fluctuated from 4 to $100 \%$ at the stage of flowering-milk ripeness. Mildew incidence was $25-50 \%$ appearing in more than $33 \%$ of fields (Fig. 1). Severity of disease ranged from 0.4 to $18 \%$, in most cases severity did not reach $5 \%$ (Fig. 1 ).

$\mathbf{A}$
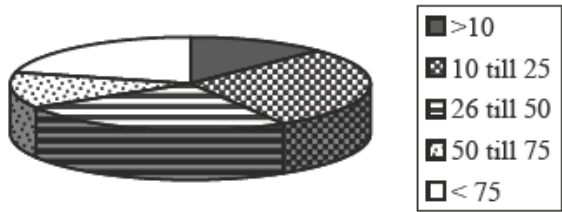

B

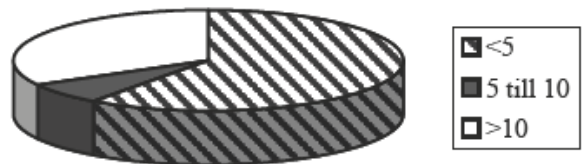

Fig. 1. The proportion of fields above the threshold reflecting differences in mildew development: A - incidence, B - severity, \%.

Low severity of disease means that significant yield losses were noted only in some cases. The more detailed investigations about characteristics of mildew development are necessary.

Incidence of Septoria blotch was high. The symptoms of disease on more than $25 \%$ of plants were recognized in $64 \%$ of the observed plots (Fig. 2). Severity was different $-0.1-90 \%$, but mostly did not exceed $5 \%$ (agronomical important level). 
A

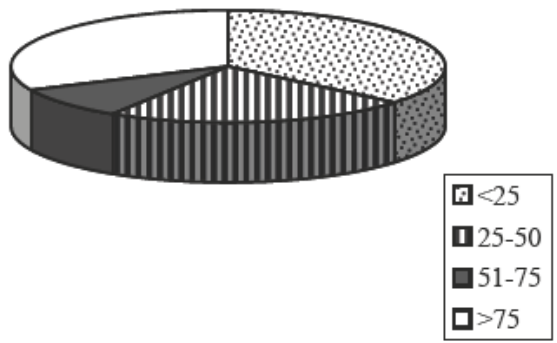

B

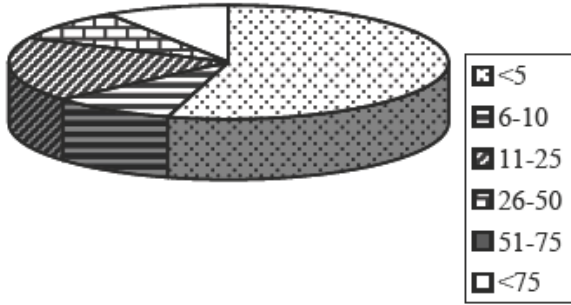

Fig. 2. The proportion of fields above the threshold reflecting differences in septoria blotch development: A - incidence, B - severity, \%.

Incidence of tan spot surpassed $50 \%$ in nearly $70 \%$ of plots, incidence lower than $25 \%$ was observed seldom (Fig.3). Severity of tan spot fluctuated from $0.5 \%$ to $99 \%$ depending on year, locality and variety, but threshold of importance (5\%) was determined in $68 \%$ of cases.

A

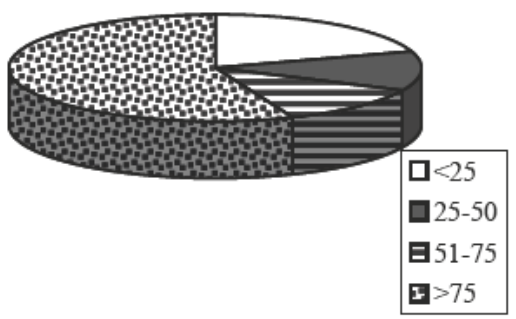

B

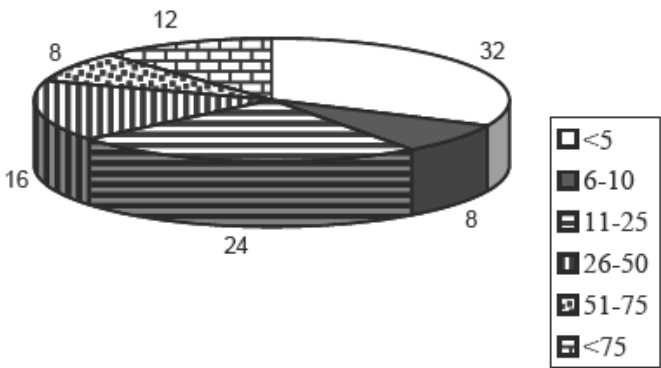

Fig. 3. The proportion of fields above the threshold reflecting differences in tan spot development: A - incidence, B - severity, \%.

The first symptoms of powdery mildew were recorded mostly in the early stages of development. Severity of the disease remained at the same level throughout the vegetation season (Fig. 4). Fluctuations in rate could be generated by the meteorological conditions, what determine dispersal and germination of conidia.

The first symptoms of leaf blotches were observed during stem elongation till ripening. The meteorological conditions were different, nevertheless characteristic 
tendencies of diseases development were reported (Fig.4). Increase of the diseases severity was slow until the stage of milk ripeness, and only in the late stages of crop development a sharp increase of leaf blotches was stated (Fig.4).

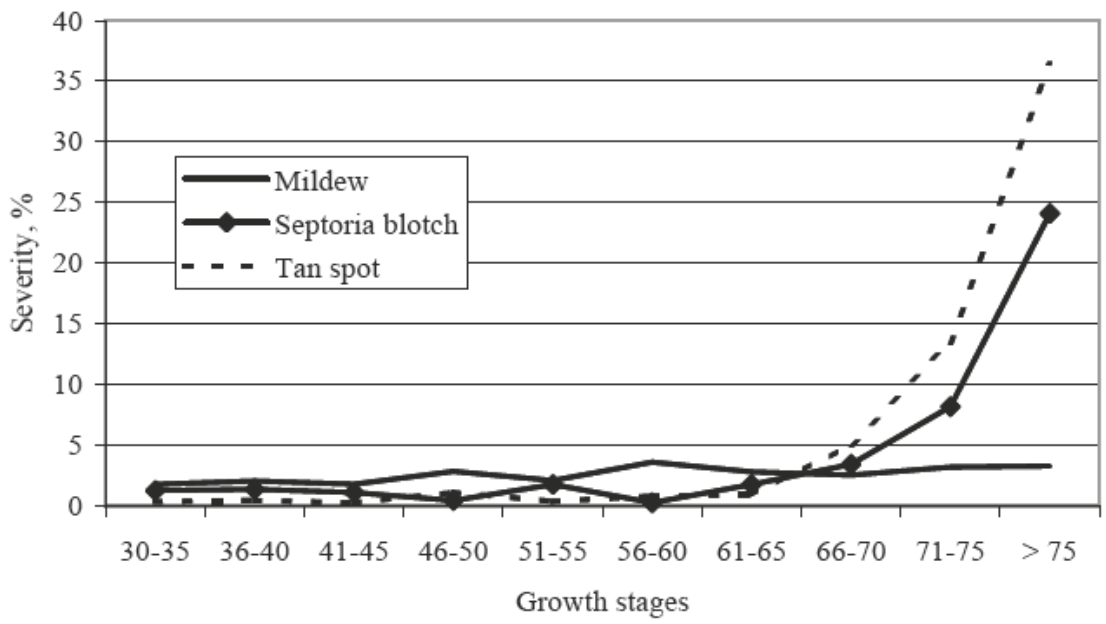

Fig. 4. Development of the wheat leaf diseases.

\section{DISCUSSION}

Differences and peculiarities of epidemics are reflected by the disease progress curves. Crucial period of leaf blotch disease development, especially tan spot, appears at the time of flowering or later. It means that leaf blotch diseases are most harmful for the late varieties with long period of ripening. Increase of the disease development was determined by reduced resistance of older wheat leaves and peculiarities of ascospores maturation and distribution. Leaf age affects the disease severity, the oldest leaves being the most susceptible (C ox and Hos for d, 1987).

Pseudotechia of Pyrenophora tritici-repentis were observed under the conditions of Latvia (Bankina, 2003), while Mycosphaerella graminicola has not been established in Latvia yet. Slope of Septoria tritici progress curve is similar to that of Drechslera tritici-repentis. It means that possibility of Septoria tritici teleomorph is very high. Ascospores were dispersed in the lower canopy, but rarely to the upper leaves (W r i $\mathrm{ght}$ and Sutton, 1990). A period of a very slow increase of the disease severity (rate of infection nearly zero) supported this view. Although conidia may not normally form on lesions prior to leaf senescence, lesions of the disease on upper leaves were usually found only after flowering. The subsequent disease development within the crop and damage to the upper leaves in summer were commonly ascribed to the anamorph 
stage, which first arises from primary ascosporic lesions and develops to give rise to splash-borne pycnidiospores produced in pycnidia (H u n t e r et al.,1999, G l a d d e r s et al., 2001).

The relative contribution of ascospores and conidia to the development of tan spot under the Latvian conditions needs further studies.

\section{LITERATURE}

B a n k in a B., 2002. Some aspects of epidemiology of fungal diseases observed on foliage of wheat in Latvia, 1998-2000. Petria Giornale di Patologia delle Piante, 12 (1/2): 193-197.

B ankina B., 2003. Tan spot development peculiarities in Latvia. Plant Prot. Sci., 2: 381$-383$.

C a m p bell C.L., Madden V.L., 1990: Introduction to plant disease epidemiology. A John Wiley\& Sons. INC New York.: 161-187.

Cox D.J., Hos ford R.M., 1987: Resistant winter wheat compared at differing growth stages and leaf positions for tan spot severity. Plant Dis. 71: 883-886

Francl L.J., 1998: Genesis and liberation on conidia of Pyrenophora tritici-repentis / Can. J. Plant Pathol. 20: 387-393.

Gladders P., Paveley N.D., Barrie I.A., Hardwick N.V., Hims M.J., L a ng to n S., Taylor M.C., 2001. Agronomic and meteorological factors affecting the severity of leaf blotch caused by Mycosphaerella graminicola in commercial wheat crops in England. Ann. Appl. Biol., 138: 301-311

Hunter T., Coker R.R., Royle D.J., 1999. The teleomorph stage, Mycosphaerella graminicola, in epidemics of septoria tritici blotch on winter wheat in the UK. Plant Pathology, 48: 51-57.

Wright K.H., S ut t o n J.C, 1990: Inoculum of Pyrenophora tritici-repentis in relation to epidemics of tan spot of winter wheat in Ontario. Can. J. Plant Pathol., 12: 149-157.

\section{Wlaściwości cyklu rozwojowego chrób liści pszenicy na Łotwie}

\section{Streszczenie}

Obserwacje polowe prowadzono w latach 1999-2004 na 29 plantacjach na Łotwie. Określano nasilenie występowania chorób liści pszenicy i stopień porażenia roślin na plantacjach. Brunatna plamistość liści powodowana przez Drechslera tritici-repentis i septorioza powodowana przez Septoria tritici okazały się najgroźniejszymi chorobami pszenicy w czasie prowadzenia badań (nasilenie występowania odpowiednio $10-100 \%$ i 1-100\%). Nasilenie występowania mączniaka prawdziwego, powodowanego przez Blomeria graminis również było wysokie (4-100\%), podczas gdy rdze (Puccinia tritici i P. striiformis) notowano tylko sporadycznie. Określano także zmiany zachodzące w czasie epifitoz i zanotowano różnice w cyklach rozwojowych pomiędzy badanymi chorobami. 